\title{
ANALISIS GEJALA AKHIR PEKAN (THE WEEKEND EFFECT) TERHADAP RETURN SAHAM LQ45 DI BURSA EFEK INDONESIA PERIODE 2016
}

\author{
Mellisa Fitri Andriyani Muzakir \\ Program Diploma III Ekonomi, Universitas Islam Indonesia \\ Email: mellisafitriandriyani@gmail.com
}

\begin{abstract}
Abstrak
Penelitian ini berjudul "Analisis Gejala Akhir Pekan (The Weekend Effect) Terhadap Return Saham LQ45 di Bursa Efek Indonesisa Periode 2016". Penelitian ini digunakan untuk melihat peristiwa anomali return periode 2016 pada indeks LQ45. Hipotesa dalam penelitian ini adalah H1: Adanya dugaan terjadi efek akhir pekan (weekend effect) yang menunjukkan adanya perbedaan return saham pada hari Jumat akan lebih tinggi dan hari Senin akan menunjukkan return yang lebih rendah. Periode penelitian ini adalah Februari 2016 sampai dengan Januari 2017 dengan total 42 Emiten yang berturut-turut masuk kedalam indeks LQ45. Uji hipotesis menggunakan uji independent sample t-test. Hasil penelitian menunjukan nilai $t$ pada equal variances assumed ( $\mathrm{t}$ hitung) adalah sebesar 1,532 dengan $\mathrm{df}=94$, dengan nilai probabilitas (Sig.) 0,129 lebih besar 0,05 maka dapat disimpulkan bahwa Ho gagal ditolak artinya tidak terdapatnya perbedaan antara rata-rata return saham hari Senin dengan rata-rata return saham hari Jumat, sehingga $\mathrm{H} 1$ ditolak.
\end{abstract}

Keyword: saham, bursa efek indonesia

\section{WEEKEND EFFECT ANALYSIS ON SHARE RETURN LQ45 IN INDONESIA STOCK EXCHANGE PERIOD 2016}

\author{
Mellisa Fitri Andriyani Muzakir \\ Program Diploma III Ekonomi, Universitas Islam Indonesia \\ Email: mellisafitriandriyani@gmail.com
}

\begin{abstract}
This study entitled "Weekend Effect Analysis on Return of LQ45 Stock in Indonesia Stock Exchange Period 2016". This research is used to see the anomaly return event of period 2016 at index LQ45. Hypothesis in this study is H1: The existence of the suspect weekend effect (weekend effect) which shows the difference of stock return on Friday will be higher and Monday will show lower return. The period of this research is February 2016 until January 2017 with a total of 42 Issuers that successively entered into LQ45 index. Hypothesis test using independent sample t-test. The result shows that the value of $t$ on equal variances assumed ( $t$ count) is 1.532 with $\mathrm{df}=94$, with probability value (Sig.) 0.129 is greater than 0.05 it can be concluded that Ho failed to be rejected means there is no difference between the average return shares on Monday with average stock returns Friday, so H1 is rejected.
\end{abstract}

Keyword: stock, stock exchange indonesia.

PENDAHULUAN
Istilah investasi dalam kehidupan sehari-hari sudah sangat melekat di benak 
masyarakat khususnya berkaitan dengan retutn atau pendapatan yang akan didapatkan suatu hari nanti. Pendapatan yang diharapkan oleh masyarakat biasanya dalam bentuk kompensasi finansial yang kemudian diharapakan mampu untuk membiayai kehidupan. Namun kurangnya pengetahuan akan investasi yang benar dan begitu menariknya investasi sehingga banyak pihak yang menyalahgunakan istilah tersebut untuk menarik konsumen sehingga bayak masyarakat yang merasa dirugikan.

Investasi merupakan penundaan konsumsi sekarang untuk dimasukkan ke aktiva produktif selama periode waktu yang tertentu (Hartono, 2010). Sudah banyak alternatif cara rinvestasi baik investasi pada aset riil, pada pengetahuan dan kompetensi maupun pada lembaga keuangan baik bank maupun non bank seperti pada pendidikan, emas, deposito, tanah, rumah, dan pada pasar modal. Khususnya pada saat ini pasar modal mendapatkan perhatian lebih dari kalangan investor, emiten mapupun pemerintah karena sangat mendukung perekonomian Indonesia. Faktor pajak menjadi aspek utama dalam pembangunan perekenomian karena investor pada pasar modal juga dikenakan pajak.

Pasar modal merupakan sarana perusahaan untuk meningkatkan kebutuhan jangka panjang dengan menjual saham atau mengeluarkan obligasi (Hartono, 2010). Pasar modal akan menjembatani pihak-pihak yang membutuhkan dana dengan investor, atau tempat yang digunakan oleh perusahaan untuk mendapatkan dana, sehingga kelebihan dana tersebut dapat dialokasikan secara efisien. Salah satu indeks saham favorit bagi investor adalah LQ-45 karena kemampuan liquiditas dan intensitas transaksi yang tinggi, sehingga indeks LQ-45 sering dijadikan acuan para investor untuk menempatkan dananya pada perusahaan-perusahaan yang tergabung dalam indeks LQ-45. Dengan adanya pasar modal diharapkan aktivitas perekonomian menjadi meningkat karena pasar modal merupakan alternatif pendanaan bagi perusahaan sehingga perusahaan dapat beroperasi dengan skala yang lebih luas dan pada akhirnya akan meningkatkan pendapatan perusahaan dan kemakmuran masyarakat luas.

Sebagai salah satu instrumen investasi, saham mengalami perubahan harga setiap harinya. Efficient Market Hyphotesis (EMH) memprediksi bahwa harga saham menunjukkan dengan instan semua informasi yang tersedia di pasar. Fakta yang muncul adalah terjadinya ketidakseimbangan aliran informasi antara para manajer sebagai insider perusahaan dengan para investor sebagai pihak 
outsider. Ketidakseimbangan informasi ini disebut asimertik informasi. (Hartono, 2010) asimetrik informasi adalah informasi privat yang hanya dimiliki oleh investor-investor yang mendapat informasi saja (informed investors).

Dalam pasar modal terdapat penyimpangan yang disebut dengan anomali pasar (market anomaly). Sejak pasar tutup pada hari sabtu dan minggu, investor tidak dapat melakukan apapun walaupun mendapatkan informasi selama sabtu dan minggu. Disinilah terdapat anomali. Istilah abnormal return dapat diterjemahkan sebagai return taknormal atau return takwajar. Disebut return taknormal (abnormal) karena merupakan return diluar normal. Return yang normal adalah return yang diperoleh dari investasi untuk kondisi yang normal. Return tak normal terjadi karena ada informasi baru yang mengubah nilai perusahaan dan direaksi oleh investor dalam bentuk kenaikan atau penurunan harga saham (Hartono, 2010). Abnormal return bisa terjadi karena peristiwa-peristiwa tertentu, seperti hari libur, awal bulan, awal tahun, penawaran saham perdana, stock-split, dan sebagainya.

Banyak penelitian yang dilakuakan untuk menguji terdapat atau tidaknya pengaruh akhir pekan diberbagai negara dengan berbagai kesimpulan. Study yang dilakukan oleh Berument dan Kiymaz
(2001) dengan menggunakan index S\&P 500 untuk periode Januari 1973 sampai dengan Oktober 1997, menemukan return tertinggi pada hari rabu, dan return terendah pada hari senin. Penelitian yang dilakukan oleh Elango and Macki (2008) dengan mengambil sample National Stock Exchange of India (NSE) pada tahun 1999- 2007, mereka menganalisis return harian indeks dengan menerepkan parameter statistik yang berbeda. Mereka menemukan bahwa return rendah terjadi pada hari senin dan jumat, sedangkan return tertinggi didapatkan pada hari rabu. Murat dan Emin (2009) meneliti mengenai eksistensi pengaruh akhir pekan pada ISE menemukan saham yang diperdagangkan dalam ISE dan kapitalisasi pasar berbasis portofolio mempunyai return yang signifikan negatif pada hari senin, dan signifikan positif pada hari kamis dan jumat.

Fenomena pengaruh akhir pekan ini menarik untuk diteliti karena memiliki pola yang hampir selalu berulang yang dapat dilihat pada return yang didapat pada setiap minggunya meskipun tidak semua menunjukan hasil yang sama atau sesuai dengan hipotesa, hal itu terjadi karena beberapa faktor yang terjadi di setiap negara yang memiliki kultur yang berbeda. Return tinggi pada hari jumat dan return rendah pada hari senin diduga 
merupakan suatu bentuk dari gejala pengaruh akhir pekan.

\section{RUMUSAN MASALAH}

Berdasarkan latar belakang yang telah diuraikan di atas dan dugaan pola yang selalu berulang tersebut, maka masalah dalam penelitian ini adalah apakah terdapat gejala akhir pekan (the weekend effect) pada return saham harian LQ45 di BEI periode 2016?

\section{TUJUAN PENELITIAN}

Tujuan dari penelitian ini adalah: untuk mengidentifikasi apakah terdapat gejala pengaruh ahir pekan (weekend effect) pada tingkat return saham harian LQ45 di BEI dimana terdapat return yang lebih tinggi dihari jumat dan return yang lebih rendah pada hari senin pada periode penelitian 2016.

\section{TINJAUAN PUSTAKA Return Saham}

Return merupakan hasil yang diperoleh dari investasi. Return dapat berupa return realisasian yang sudah terjadi atau return ekspektasian yang belum terjadi tetapi yang diharapkan akan terjadi dimasa yang akan datang (Hartono, 2010).

Capital Gain atau Capital Loss $=$ $\frac{P_{t}-P_{t-1}}{P_{t-1}}$

Dimana:
$\mathrm{Pt}=$ harga investasi

sekarang

$$
\mathrm{Pt}-1=\text { harga investasi }
$$

periode lalu

\section{Expected Return}

Expected return atau return ekspektasian merupakan return yang diharapakan oleh investor terhadap investasi yang dilakukannya dimasa yang akan datang. Sifat dari return ekspektasian ini adalah return yang belum terjadi.

\begin{abstract}
Abnormal Return
Abnormal return atau excess return merupakan kelebihan return dari return yang sesungguhnya terjadi terhadap return normal (Jogiyanto, 2010). Abnormal return yang didapatkan oleh investor merupakan return yang tidak sesuai dengan harapan investor. Abnormal return menjadi positif jika return yang diharapakan lebih besar dari return yang didapatkan. Sedangkan abnormal return menjadi negatif jika return yang diharapkan lebih sedikit dari return yang didapat.
\end{abstract}

\section{Efficient Market Hypothesis (EMH)}

Eugene dan Joel (2010) mengatakan efficient market hypothesis merupakan hipotesis yang menyatakan bahwa efek pada umumnya berada dalam 
keadaan equilibrium - bahwa saham tersebut dihargai secara wajar dalam artian harganya telah mencerminkan seluruh informasi tentang saham yang tersedia bagi publik.

\section{Amonali pasar}

Jones (1996) dalam Hartono mendifinisikan anomali pasar sebagai tekhnik atau strategi yang tampaknya bertentangan dengan pasar efisien. Saham-saham yang biasanya diminati oleh pasar bisa menjadi kurang diminati, sedangkan saham-saham yang kurang diminati dengan return rendah akan dicari oleh pasar.

\section{Penelitian Terdahulu}

Penelitian tentang pengaruh akhir pekan (the weekend effect) telah banya dilakukan sebelumnya. Penelitian yang dilakukan oleh Nasir, Mohamad dan Hamid (1988) di Malaysia mengemukakan selama periode 1975 1985 return rata-rata terendah berlaku pada hari selasa dan baik pada hari senin dan selasa mempunyai return yang negatif. Penelitian lain yang dilakukan oleh Muhammad \& Rahman (2010) meneliti di Malaysian Exchange pada periode 1996 - 2006 menemukan bahwa pola weekend effect terdapat di Malaysia. Penelitian yang dilakukan oleh Elango and Macki (2008) dengan mengambil sample National Stock Exchange of India (NSE) pada tahun 1999 - 2007, mereka menganalisis return harian indeks dengan menerepkan parameter statistik yang berbeda. Mereka menemukan bahwa return rendah pada hari senin dan jumat.

\section{Hipotesis}

H1: Diduga terjadi efek akhir pekan (weekend effect) yang menunjukkan adanya perbedaan return saham pada hari Jumat akan lebih tinggi dan hari Senin akan menunjukkan return yang lebih rendah

\section{METODE}

\section{Uji Hipotesis}

Dalam penelitian ini manggunakan dua variabel yang akan diteliti, yaitu variabel hari perdagangan dan variabel return saham. Perhitungan pada variabel return saham sebagai variabel terikat menggunakan Logaritma Natural untuk menghindari bias agar return yang dihasilkan mendekati normal, maka rumus yang digunakan adalah:

$$
\text { Ri,t }=\text { LN (Pi,t / Pi,t-1) }
$$

Dimana:

$$
\begin{aligned}
\text { Ri,t } & =\text { Return saham pada hari } \\
& \text { ke } \mathrm{t} \\
\mathrm{P}_{\mathrm{i}, \mathrm{t}} & =\text { Harga penutupan pada } \\
& \text { hari ke } \mathrm{t} \\
\mathrm{P}_{\mathrm{i}, \mathrm{t}-1} & =\text { Harga penutupan pada } \\
& \text { hari ke } \mathrm{t}-1
\end{aligned}
$$


Pengujian hipotesis menggunakan uji independent sample t-test. Adapun langkahnya sebagai berikut:

a. Hipotesis

$\mathrm{H}_{0}: \beta=0$ yang berarti tidak terdapat perbedaan antara return saham hari Senin dengan return saham hari Jumat

$\mathrm{H}_{\mathrm{a}}: \beta \neq 0$ yang berarti tidak terdapat perbedaan antara return saham hari Senin dengan return saham hari Jumat

b. Menggunakan tingkat keyakinan 95 persen

c. Membuat kesimpulan berdasarkan perumusan hipotesis yaitu; apabila $\mathrm{t}$ hitung lebih kecil dari $\mathrm{t}$ tabel (sig. lebih besar dari alpha) maka $\mathrm{H}_{0}$ gagal ditolak dan apabila $\mathrm{t}$ hitung lebih besar dari $\mathrm{t}$ tabel (sig. lebih kecil dari alpha) maka $\mathrm{H}_{0}$ ditolak dan weekend effect terjadi bila rata-rata return saham hari Jumat tertinggi dan positif.

Data harga saham harian yang digunakan adalah harga saham penutupan (closing price) periode Februari 2016 Januari 2017. Adapun perusahan yang terus menerus terdaftar dalam index LQ45 selama periode tersebut terlihat dalam table berikut ini:

Tabel 1. Daftar Perusahaan yang Tercatat dalam index LQ45 Periode Februari 2013 sampai dengan Juli 2015

\begin{tabular}{lcllllll}
\hline No & Code & No & Code & No & Code & No & Code \\
\hline 1 & AALI & 12 & BMRI & 23 & KLBF & 34 & SCMA \\
2 & ADHI & 13 & BMTR & 24 & LPKR & 35 & SILO \\
3 & ADRO & 14 & BSDE & 25 & LPPF & 36 & SRIL \\
4 & AKRA & 15 & CPIN & 26 & LSIP & 37 & SSMS \\
5 & ANTM & 16 & GGRM & 27 & MNCN & 38 & TLKM \\
6 & ASII & 17 & HSMP & 28 & MPPA & 39 & UNTR \\
7 & ASRI & 18 & ICBP & 29 & MYRX & 40 & UNVR \\
8 & BBCA & 19 & INCO & 30 & PGAS & 41 & WIKA \\
9 & BBNI & 20 & INDF & 31 & PTBA & 42 & WSKT \\
10 & BBRI & 21 & INTP & 32 & PTPP & & \\
11 & BBTN & 22 & JSMR & 33 & PWON & & \\
\hline
\end{tabular}

\section{HASIL DAN PEMBAHASAN}

Analisis ini diperlukan untuk mengetahui gambaran data return LQ45 tahun 2016 di Bursa Efek Indonesia. Hasil analisis deskriptif dapat dilihat pada tabel 2 .
Analisis statistik deskriptif menunjukkan bahwa nilai minimum untuk hari senin adalah $-1,02027$ dan nilai maksimum 0.932115. Untuk hari Selasa nilai minimum untuk hari senin adalah 1.0254 dan nilai maksimum 0.676711 . Untuk hari Rabu nilai minimum untuk 
hari senin adalah -0.64854 dan nilai maksimum 1.138138. Untuk hari Kamis nilai minimum untuk hari senin adalah 0.84383 dan nilai maksimum 1.021357 . Untuk Jumat nilai minimum adalah 1.73972 dan nilai maksimum 0.85711 . Sedangkan rata-rata return tertinggi pada hari Rabu dan terendah pada hari Jumat 0.12583 dan -0.10186. Hal ini senada dengan hasil penelitian-penelitian yang pernah dilakukan sebelumnya yang menolak adanya anomali return. Study yang dilakukan oleh Berument dan Kiymaz (2001) dengan menggunakan index S\&P 500 untuk periode Januari 1973 sampai dengan Oktober 1997, menemukan return tertinggi pada hari rabu, dan return terendah pada hari senin.
Penelitian yang dilakukan oleh Elango and Macki (2008) dengan mengambil sample National Stock Exchange of India (NSE) pada tahun 1999- 2007, mereka menganalisis return harian indeks dengan menerepkan parameter statistik yang berbeda. Mereka menemukan bahwa return rendah terjadi pada hari senin dan jumat, sedangkan return tertinggi didapatkan pada hari rabu. Murat dan Emin (2009) meneliti mengenai eksistensi pengaruh akhir pekan pada ISE menemukan saham yang diperdagangkan dalam ISE dan kapitalisasi pasar berbasis portofolio mempunyai return yang signifikan negatif pada hari senin, dan signifikan positif pada hari kamis dan jumat.

Tabel 2. Hasil Analisis Statistik Deskriptif

\begin{tabular}{lccccc}
\hline & N & Minimum & Maximum & Mean & Std. Deviation \\
\hline Senin & 52 & -1.02027 & 0.932115 & 0.03267 & 0.45539 \\
Selasa & 52 & -1.0254 & 0.676711 & 0.00051 & 0.33694 \\
Rabu & 49 & -0.64854 & 1.138138 & 0.12583 & 0.35071 \\
Kamis & 50 & -0.84383 & 1.021357 & 0.02890 & 0.38831 \\
Jumat & 49 & -1.73972 & 0.85711 & -0.10186 & 0.42516 \\
\hline
\end{tabular}

Sumber : Data sekunder diolah

Study yang dilakukan oleh Berument dan Kiymaz (2001) dengan menggunakan index S\&P 500 untuk periode Januari 1973 sampai dengan Oktober 1997, menemukan return tertinggi pada hari rabu, dan return terendah pada hari senin. Penelitian yang dilakukan oleh Elango and Macki (2008) dengan mengambil sample National Stock
Exchange of India (NSE) pada tahun 1999- 2007, mereka menganalisis return harian indeks dengan menerepkan parameter statistik yang berbeda. Mereka menemukan bahwa return rendah terjadi pada hari senin dan jumat, sedangkan return tertinggi didapatkan pada hari rabu. Murat dan Emin (2009) meneliti mengenai eksistensi pengaruh akhir pekan 
pada ISE menemukan saham yang diperdagangkan dalam ISE dan kapitalisasi pasar berbasis portofolio mempunyai return yang signifikan negatif pada hari senin, dan signifikan positif pada hari kamis dan jumat.

\section{a. Pengujian Hipotesis}

Pengujian hipotesis pertama test namun sebelum menguji hipotesis pertama dengan uji independent sample ttest harus memenuhi syarat terdistribusi normal. Uji normalistas menggunakan uji One-Sample Kolmogorov-Smirnov. Hasil dari uji normalitas dapat dilihat pada tabel 3:

menggunakan uji independent sample t-

Tabel 3. Hasil Uji Normalitas

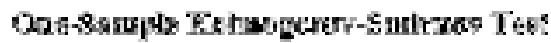

\begin{tabular}{|c|c|c|}
\hline & & reming \\
\hline $\mathbf{N}$ & & 96 \\
\hline \multirow[t]{2}{*}{ 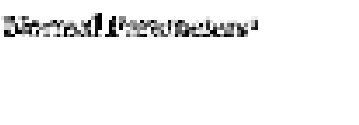 } & Betwik. & -4350 \\
\hline & Ftel. Drapision & A3,317 \\
\hline \multirow[t]{3}{*}{ 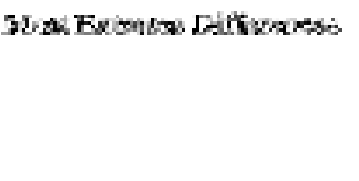 } & Altavites & $\sqrt{5} \times 8$ \\
\hline & Poektsis & 5 \\
\hline & Thegntivs & $-4 T 8$ \\
\hline Latangaxy-Spaiquxy Z & & .26 \\
\hline Jxyruy. Sip- (2-itiked) & & $.60 ?$ \\
\hline
\end{tabular}

Sumber : Data sekunder diolah

Berdasarkan tabel 3 dapat dilihat bahwa nilai Asymp. Sig. (2-tailed) sebesar 0,607 lebih besar dari $\alpha=5$ persen sehingga data yang digunakan dinyatakan berdistribusi normal dan layak menggunakan uji statistik sebagai teknik analisis data parametik. Langkah selanjutnya adalah pengujian independent sample t-test. Hasil pengujian independent sample t-test dapat dilihat pada tabel 4:

Hasil pengujian menunjukkan $\mathrm{F}$ hitung Levene test sebesar 0,657 dengan sig. 0,419 lebih besar 0,05, maka dapat disimpulkan bahwa Ho gagal ditolak yaitu variansi pada tiap kelompok sama. Dari hasil perhitungan uji independent sample t-test dapat dilihat bahwa nilai $\mathrm{t}$ pada equal variances assumed (t hitung) adalah sebesar 1,532 dengan $\mathrm{df}=94$, dengan nilai probabilitas (Sig.) 0,129 lebih besar 0,05 maka dapat disimpulkan bahwa Ho gagal ditolak artinya tidak terdapatnya perbedaan antara rata-rata return saham hari Senin dengan rata-rata return saham hari Jumat, sehingga $\mathrm{H} 1$ ditolak. 
Tabel 4. Hasil Uji One Sample T-Test

Independent Samples Test

\begin{tabular}{|c|c|c|c|c|c|c|c|c|c|}
\hline & & \multicolumn{2}{|c|}{$\begin{array}{l}\text { Levene's } \\
\text { Test for } \\
\text { Equality of } \\
\text { Variances }\end{array}$} & \multicolumn{6}{|c|}{ t-test for Equality of Means } \\
\hline & & & & & $\begin{array}{l}\text { Sig. } \\
(2- \\
\text { tailed }\end{array}$ & $\begin{array}{l}\text { Mean } \\
\text { Differen }\end{array}$ & $\begin{array}{l}\text { Std. } \\
\text { Error } \\
\text { Differe }\end{array}$ & $\begin{array}{l}95 \% \text { Cor } \\
\text { Interval } \\
\text { Differen }\end{array}$ & $\begin{array}{l}\text { nfidence } \\
\text { of the } \\
\text { cee }\end{array}$ \\
\hline & & $\mathrm{F}$ & Sig. & $\mathrm{df}$ & ) & ce & nce & Lower & Upper \\
\hline \multirow[t]{2}{*}{ return } & $\begin{array}{l}\text { Equal } \\
\text { variances } \\
\text { assumed }\end{array}$ & .657 & .419 & $\begin{array}{l}1.53 \\
2\end{array}$ & .129 & .13453 & .08782 & -.03983 & .30890 \\
\hline & $\begin{array}{l}\text { Equal } \\
\text { variances not } \\
\text { assumed }\end{array}$ & & & $\begin{array}{ll}1.53 & 93.5 \\
1 & 97\end{array}$ & .129 & .13453 & .08786 & -.03993 & .30900 \\
\hline
\end{tabular}

Sumber : Data sekunder diolah

\section{KESIMPULAN}

Kesimpulan pada penelitian ini adalah sebagai berikut:

1. Berdasarkan hasil analisa statistik diskriptif menunjukan bahwa return tertinggi adalah pada hari rabu, sedangkan hari jumad tidak lebih tinggi dari pada hari rabu. Hal ini tentu saja tidak mendukung teori weekend effect yang menyatakan return tertinggi di hari jumad.

2. Berdasarkan hasil analisa statistik diskriptif menunjukan bahwa return pada hari jumad merupakan return yang paling rendah diantara hari perdagangan lainnya. Hal ini tentu saja berlawanan dengan toeri yang menyebutkan bahwa return hari senin merupakan return terendah.

\section{DAFTAR PUSTAKA}

Brown, SJ, dan Warner, JB. (1985). Using Daily Stock Returns: The Case of Event Studies, Journal of Financial and Strategic Decision, 8(1): 15-20.

Brument, H., dan Kiymaz, H, (2001). "The Day of the Week Effect on Stock Market Volatility", Journal of Economics and Finance, Volume 25, Number 2.

Elangno, dan Macki, (2008). "Monday Effect and Stock Retur Seasonality:Further Empirical Evidence", The Business Review, Cambridge, Vol. 10, Num. 2.

Eugene F. Brigham and Joel, F Huston (2010), Manajemen Keuangan, Edisi Kedelapan, Erlangga.

Fama, E. F, (1991). "Efficient Capital Markets: II", The Journal of Finance, vol. XLVI, No. 5.

Hartono, Jogiyanto., (2010). Teori Portfolio dan Analisis Investasi, Edisi Ketujuh, BPFE: Yogyakarta.

Muhammad dan Rahman. (2010). "Efficient Market Hypothesis and 
Market Anomaly: Evidence from Day-of-the Week Effect of Malaysian Exchange", International Journal of Economics and Finance, Vol. 2, No.2.

Murat, C., dan Emin, A, (2001). "Examining the Day of The Week Effect in Istanbul Stock Exchange", International Business \& Economics Research Journal, Vol.8, Num.11

Nasir, Mohamad dan Hamid.,(1988)," Stock Returns and the Weekend Effect:the Malaysian Experience", Pertanika 11(1), 107 - 114. 